\title{
Script Reforms in Early Soviet Ethnic Policy
}

\author{
V.I.Musaev
}

For citation: Musaev V.I. Script Reforms in Early Soviet Ethnic Policy. Vestnik of Saint Petersburg University. History, 2019, vol.64, iss. 4, pp. 1287-1300. https://doi.org/10.21638/11701/spbu02.2019.408

The article deals with the activities if the Soviet leadership in the field of reforming the alphabets of the "national" languages as an integral part of ethnic policy in the USSR in the nineteen twenties and thirties. The conclusion made is that the alphabetic Latinization, which reached its peak in the early thirties, was connected with the social aspect of the ethnic policy. Creation of the new alphabets was to serve the objectives of socialist construction, international education and overcoming "remnants of the past". The latter was concerned in particular with the use of Arabic script for the alphabets of the peoples of the Caucasus, the Volga region and Central Asia, who traditionally practiced Islam. In the twenties and early thirties, activities on transfering national alphabets, previously based on either the Arabic or Cyrillic scripts or even hieroglyphic writing, were in progress. New alphabets were also modelled on the Latin script. In total in the early thirties, 66 alphabets were Latinized, and Latinization of several more was continuing. There were projects to Latinize even the very Russian alphabet but they were not implemented. Curtailing the process of Latinization and the opposite trend of substituting the Latin script with the Cyrillic one started in the mid-thirties was concerned with the revision of the general points of the Soviet ethnic policy, first of all, with the abandonment of the main principles of indigenization. One can see here also a reflection of a partial rehabilitation of the historic role of the Russian culture and promotion of the Russian nation to the position of "the first among the equal ones" among the peoples of the USSR.

Keywords: Ethnic policy, script issues, neo-Arabism, Latinization, Cyrillic alphabet.

\section{Проблемы письменности в ранней советской этнополитике}

\section{В. И. Мусаев}

Для цитирования: Musaev V.I. Script Reforms in Early Soviet Ethnic Policy // Вестник СанктПетербургского университета. История. 2019. Т. 64. Вып. 4. С. 1287-1300. https://doi.org/10.21638/11701/spbu02.2019.408

В рамках исследования была поставлена задача рассмотреть действия советского руководства в области преобразования алфавитов национальных языков как составную

Vadim I.Musaev - Doctor in History, St. Petersburg Institute of History of the Russian Academy of Science, 7, Petrozavodskaya ul., St. Petersburg, 197110, Russian Federation;Visiting Researcher, St. Petersburg State University, 7-9, Universitetskaya nab., St. Petersburg, 199034, Russian Federation; vmusaev62@mail.ru

Вадим Ибрагимович Мусаев - д-р ист. наук, Санкт-Петербургский институт истории РАН, Российская Федерация, 197110, Санкт-Петербург, Петрозаводская ул., 7; приглашенный исследователь, Санкт-Петербургский государственный университет, Российская Федерация, 199034, СанктПетербург, Университетская наб., 7-9; vmusaev62@mail.ru

This article was prepared with the support of grant No. 15-18-00119 of the Russian Science Foundation. Статья подготовлена при поддержке гранта № 15-18-00119 Российского научного фонда.

(c) Санкт-Петербургский государственный университет, 2019 
часть этнополитики в СССР в 1920-1930-е гг. Делается вывод, что алфавитная латинизация, пик которой пришелся на начало 1930-х гг., была связана с социальной стороной национальной политики: создание новых алфавитов служило задачам социалистического строительства, интернационального воспитания и преодоления «пережитков прошлого». Последние усматривались, в частности, в использовании в языках народов Кавказа, Поволжья и Средней Азии, традиционно исповедовавших ислам, письменности на основе арабской графики. Новые алфавиты для бесписьменных в прошлом языков также формировались на базе латинского шрифта. Всего в начале 1930-х гг. было латинизировано 66 национальных алфавитов и еще несколько находились в стадии разработки. Имелся даже замысел латинизировать русский алфавит, однако подобные намерения встретили серьезные возражения и не были реализованы. Сворачивание латинизации и противоположная тенденция к замене латинского шрифта алфавитов национальных языков на кириллический с середины 1930-х гг. имели связь с пересмотром общих положений национальной политики, в первую очередь с отказом от основных принципов так называемой коренизации. В этом также проявилась начавшаяся в тот же период частичная реабилитация исторической роли русской культуры и выдвижение русского народа на позиции «первого среди равных» среди народов СССР. К началу 1940-х гг. процесс перевода алфавитов национальных языков на кириллическую основу был в основном завершен.

Ключевые слова: этнополитика, коренизация, языковой вопрос, латинский алфавит, кириллица.

After coming to power, the Bolshevist leaders undertook radical reforms in various fields of the social life. This also concerned, among other aspects, the sphere of script. In 1918, the well-known reform of the Russian orthography was implemented (according to the Decree of the All-Russian Central Executive Committee "On introduction of the new orthography" of October 10, 1918). This reform proved to be the first step on the way of orthographic changes. The objective was to reform the alphabets of the literary languages of other ethnic groups as well as to create new alphabets for the languages which had not had their own script and had existed only in the oral form. During the imperial period, alphabets of literary languages of some peoples of Russia was formed on the basis of the Cyrillic script, while in the languages of the Turkic, Iranian-speaking and some Caucasian peoples, who traditionally practiced Islam, the Arabic script, adapted to the phonetics of these languages, was in use.

Attempts to substitute the Latin script with other kinds of writing were made in the nineteenth and the early twentieth centuries in various countries (Turkey, Iran, Japan), but to no avail. The only script reform, prior to those undertaken in Russia / USSR, had been implemented in Albania when this country obtained independence (in 1912). In 1919, the People's Commissariat for Education (Narkompros) put forward the issue of transferring the "national" alphabets from the Cyrillic and the Arabic scripts to the Latin one. An opinion was voiced that the Western Latin alphabet would become a logical complement to the metric system and the Gregorian calendar. To the most idealistic among the Soviet educators, the Latin alphabet would finally end Russia's "script separatism" and serve as a convergence of the Soviet nations ${ }^{1}$. The first national alphabet on the base of the Latin script was made up in 1917 by a Yakut educator and philologist S. A. Novgorodov and ad-

${ }^{1}$ Smith M. G. Language and Power in the Creation of the USSR 1917-1953. Berlin; New York, 1998. P. 104 . 
opted in 1919. Some regions of the Northern Caucasus - Ingushetia, Ossetia and Kabar$\mathrm{da}-$ followed The Yakut pattern in the early twenties. A well-known specialist in the Caucasian languages N. F. Yakovlev took an active part in the process of script reforms there. The Latin base for the writing of the mountain peoples was approved of by a decree of the Conference on issues of the enlightenment of highlanders in Pyatigorsk in April 1923. New alphabets based on the Latin script were planned also for Chechnya and Adygea ${ }^{2}$.

Supporters of the script reform were especially active in Azerbaijan. In December 1921, a discussion was in progress between the "Arabists" and the "Latinists". The former argued that, first, with transfer to the new script all available literature would be "buried"; second, there were too few literate persons, who then would become also illiterate; and third, transition to the new system would be very costly. Counter arguments were as follows: there were in fact plenty of books in the Arabic script, but there were mainly ecclesiastic books in the Arabic and the Farsi languages, the number of the secular publications was minimum; the number of literate persons among the Turkic peoples was insignificant; liquidation of illiteracy with the new alphabet would pass much faster and would cost eventually much less ${ }^{3}$.

One of the most active proponents of the alphabet reforms was Samed Agamaly-ogly, from May 1922 on - the chairman of the Central Executive Committee of the Azerbaijan Republic. In 1922, he raised the issue of substitution the old alphabet with the new one in a conversation with V.I.Lenin ${ }^{4}$. In March 1922, S. Agamaly-ogly headed a commission in Azerbaijan, which soon presented a project of the new alphabet based upon the Latin script. After a discussion this project was approved of by the republican authorities, an on July 21 of the same year a Committee on implementation of the new Turkic alphabet with Agamaly-ogly at its head was established ${ }^{5}$. Already in 1921, an issue of latinization of the alphabet was raised in Uzbekistan, but then the idea could not win a sufficient number of supporters. In 1923, movement for the new alphabet involved Bashkiria. At first several groups and then a committee on latinization of the alphabet were organized. The absence of any literature in the Bashkir language facilitated the transition to the new alphabet ${ }^{6}$. The prevalence of the Latin alphabet was one of the main arguments put forward by the Latinists. They pointed out revolutionary integration processes, which went on in the world, and came to conclusion that "the Latin alphabet is becoming the uniform world alphabet", "the alphabet of the victorious proletariat"7. The new alphabet was recognized in Azerbaijan on equal terms with the Arabic one by the decree of the republican CEC of October 20,1923 , and by the decree of June 27, 1924, it was declared official and obligatory. From September 1922, the newspaper "Jeni Jol" ("New Path") began to be printed in Azerbaijan in the new script. At first it was weekly, and from December 1924 - became daily. There

${ }^{2}$ Ibid. P. 123; Petrov N. E. Alfavit yakutskogo yazyka // Voprosy sovershenstvovania alfavitov tiurkskikh narodov SSSR. Moscow, 1972. P. 209.

3 Agazade F., Karakashly K. Ocherk po istorii razvitia dvizhenia novogo alfavita i ego dostizhenia. Kazan', 1928. P. 58-60.

${ }^{4}$ Pavlovich $M$. K istorii i zadacham tiurkologicheskogo s'ezda // V bor'be za novyi tiurkskii alfavit. Sbornik statey. Moscow, 1926. P. 4.

${ }^{5}$ Isaev M. I. Iazykovoe stroitel'stvo v SSSR (protsessy sozdania pis'mennosti narodov SSSR). Moscow, 1979. P. 63-64.

${ }^{6}$ Kul'besherov B. Itogi 2-go Plenuma Vsesoyuznogo tsentral'nogo komiteta novogo tiurkskogo alfavita i ocherednye zadachi dela vvedenia etogo alfavita // Kul'tura i pis'mennost' Vostoka. 1928. No. 2. P.9, 11.

7 Isaev M. I. Iazykovoe stroitel'stvo v SSSR... P. 54. 
had been 21,774 people literate in the new alphabet by 1925, and 231,531 people by 1928 . In 1923 and 1924, the new alphabet started to be introduced among the Turkic residents in Georgia and Armenia ${ }^{8}$.

The Latinization project caused an ambiguous reaction in the party environment as well as among the specialists. V. I. Lenin supported latinization along these equivocal lines, believing it was beneficial in principle, but premature. A. V. Lunacharsky even recounted a 1918 conversation with him on the subject. "I do not doubt", Lenin allegedly said, "that the time will come for the latinization of the Russian script but to act in haste would be unwise". Leading Russian linguists tabled the proposal offering their general support, but their opposition in fact, given the practical complications of a new Latin alphabet. Kazakh public activist and linguist A. Baitursunov referred to both Russian and Latin scripts as chaotic and improper to the Turkic mind. Instead, he created a more popular, phonetic neo-Arabic script for Kazakh speakers. In Kazan, well-known philologists G. Sharaf and G. Ibragimov, who were also opponents of latinization of the Turkic script, offered their own version of the neo-Arabic alphabet. Similar projects were set up by local linguists for other Turkic and some Caucasian languages. Even E. D. Polivanov, a dedicated supporter of latinization of the scripts, praised activities of the neo-Arabists and especially the one by A. Baitursunov'.

In 1923, a Commission for reform of the Arabic script was established within the Narkompros. The members of this commission could not agree on the issue of the alphabet reform. Some favored a common, simplified Arabic script. Others proposed a Russian model so that "all peoples of the East will move to a general, European culture through the medium of the Russian language". Yet another group advocated the new Latin script given its success in the Northern Caucasus and Azerbaijan. The chairman, N.F. Tyuryakulov, favoured a reform of the Arabic scripts in the short term and introduction of the Latin script in the long. He argued that the government should not ignore advantages and popularity of various Arabic scripts and introduce the Latin script by decree. The commission eventually failed to render any unequivocal decision ${ }^{10}$.

The Central Committee of the RCP (b) continued to support Latinization in Azerbaijan and the Northern Caucasus, but still abstained from implementing a thorough reform in other republics and regions. Among the main adepts of the Latinization project were Turkic communists: S. Agamaly-ogly, U. Aliev from Karachai, Crimean Tatar linguist B. Choban-zade ${ }^{11}$, and the party and state leader of Dagestan J.Korkmasov, Kumyk by origin (the Kumyks are the only Turkic ethnic group in multinational Dagestan). They promoted latinization as "an important stage in creation of a new Turkic-Tartar culture". The Azerbaijanis sent teachers and activists to the Northern Caucasus and Central Asia to organize societies of friends of the new alphabet, providing them with funding and printed materials. According to Michael Smith's presumption, it was "a novel kind of pan-Turkism based on the model of their New Turkic Alphabet"12.

8 Agamaly-ogly S. V zashchitu novogo tiurkskogo alfavita. Baku, 1927. P. 8-12.

9 Smith M. G. Language and Power in the Creation of the USSR. P. 122.

10 Ibid. P. 125.

11 Bekir Choban-zade between 1922 and 1924 was professor, then rector of the Tauris National University, in 1924 arrived in Baku on invitation of the Azerbaijani leadership, between 1924 and 1929 occupied the post of head of a department at the Baku University, between 1930 and 1935 worked in Uzbekistan.

12 Smith M. G. Language and Power in the Creation of the USSR. P. 125. 
In 1924, a discussion on the alphabet question was initiated in the magazine "Zhizn' Natsional'nostey" (Life of Nationalities"). One of the supporters of the reform, Z. Navshirvanov, pointed out, among other problems, technical difficulties of working with the Arabic script. He also wrote that the manner of the Arabic writing - from right to left - was complicated and slowed down typesetting texts written in the Arabic script, and this work was one and a half times more expensive than typesetting in the Western scripts ${ }^{13}$. The Latinists also noted that of 28 characters of the Arabic alphabet only 16 had their own lettering, while the rest differed from one another only by various superscript and subscript diacritic signs, which could not but complicate their tracing and printing. Besides, almost all letters had two or three versions of writing according to their position in a word: at the beginning, in the middle or at the end ${ }^{14}$. They also referred to such substantial defects of the Arabic alphabet as the absence of vowels and the existence of the letters, unsuitable for pronunciation ${ }^{15}$. S. Agamaly-ogly explained the success of the new Turkic alphabet in Azerbaijan by "its exclusive accessibility and simplicity as compared with the others". He also argued that "from the Arabic likpunkts (literacy centers. - V.M.), which operated alongside reform attempts, , people moved on en masse to new schools". He maintained that the Latin alphabet was closer to the Turkic phonetics that the Russian one, which justified the reason why the new Turkic alphabet should be formed on the base of the Latin rather than on the Cyrillic script ${ }^{16}$.

One of the opponents of Latinization, G. Broido, deputy commissar on the nationalities affairs, put forward an argument that the Arabic alphabet also could be reformed. Having admitted that it had some defects, he mentioned: "Such defects were also present in our alphabet, but we have altered the spelling rules. The same can be done to the Arabic alphabet, which is used by a larger number of people than the Latin one". The author drew attention to the fact that the number of characters in the Arabic alphabet is fewer than in the Latin one, that just the system of diacritical points reduced their number. He argued that "absence of special signs for writing and printing, absence of capital and small letters ranks the principles of the Arabic script higher since they are easier"17. G. Sharaf, defending advantages of the Arabic script, pointed out that the writing direction of the Arabic script from right to left corresponded to the physiological laws. G. Ibragimov in his article "Cultural-literary federation among the Turkic peoples", published in a digest of articles edited in Kazan, tried to connect the Latinization movement with missionary and Christian influence as well as with an alleged threat of assimilation ${ }^{18}$.

Attitude of the Soviet party and state leaders towards the alphabet issue was at first rather reserved and careful. They abstained from presenting themselves as immediate supporters of latinization lest their relations with the Muslim activists loyal towards the Soviet power be worsened. From 1922, they began to display their position more clearly. For instance, J.Stalin, S. Kirov, A. Mikoyan were in favor of Latinization. It was connected

${ }^{13}$ Navshirvanov Z. Pochemu my stremimsia pereiti k latinskomu alfavitu // V bor'be za novyi tiurksky alfavit. Baku, 1926. P. 47-48.

${ }^{14}$ Zak L.M., Isaev M.I. Problemy pis'mennosti narodov SSSR v kul'turnoy revoliutsii // Voprosy istorii. 1966. No.2. P.6.

15 Yuzbashev N. Arabsky i Novo-Tiurksky alfavit // Kul'tura i pis'mennost' Vostoka. 1928. No. 1. P. 65.

16 Agamaly-ogly S. V zashchitu novogo tiurkskogo alfavita. P. 14, 82.

17 Broido G. K voprosu o zamene arabskogo alfavita latinskim // V bor'be za novy tiurksky alfavit. P. 42,53 .

18 Agamaly-ogly S. V zashchitu novogo tiurkskogo alfavita. P. 17, 65-68, 87. 
with aspirations of the Soviet leaders to unite cultural interests with political needs. The Latin alphabet as derived from outside was not associated with the "great Russian chauvinism" and imperial Russification policies. And as soon as Latinization movement in Yakutia, Azerbaijan and the Northern Caucasus looked took the shape of local initiatives, the party, by rendering support to it, contributed to implementing the indigenization policy and helped to create new alphabets or reform the old ones in order to spread literacy and universal education ${ }^{19}$. According to the opinion voiced by a well-known linguist L. Zhirkov, "the tsarist regime rigidly enforced the Russian alphabet everywhere, and for this reason everybody has been turning away and continues to turn away from the Russian alphabet. And the Latin alphabet has no odious past of that kind. Moreover, it possesses such a quality,valuable for our present day as a very high degree of internationalization" 20 .

Early in 1924, the all-Union Scholarly Association of Oriental Studies (VNAV) ${ }^{21}$ put forward an issue of convoking the all-Union Turkological Congress. In April of the same year a special commission for preparation work for the congress was established within the Association. Soon afterwards, a digest of articles "Struggling for the new Turkic alphabet" was published. M. Pavlovich, chairman of VNAV, wrote in this digest: "The issue of unsatisfactory state and imperfection of alphabets, script, terminology, orthography, methods of instruction and other main cultural elements of the Turkic-Tatar languages has been on the agenda in all Soviet republics and provinces with the Turkic-Tatar population since the end of the civil war and defeat of couner-revolution. Since the beginning of the age of peace construction the goal of educating broader popular masses with the assistance of their mother tongue has acquired a paramount importance"22. S. Agamaly-ogly in his article "To the forthcoming Turkological congress in Azerbaijan" noted: "In the Tatar Republic, Uzbekistan, Turkmenistan, etc. the Arabic alphabet has been 'reformed' in such a way that the old one has been abandoned and the new one has not eradicated huge defects of this alphabet. For example, mathematic calculations are made from left to right, and the text goes from right to left, etc." 23

On June 17, 1925 VNAV addressed the following petition to the Presidium of the CEC of the USSR: "In view of numerous proposals from the party, Soviet and scientific institutions to convoke the all-Union Turkological Congress, the Scientific Association of Oriental Studies of the USSR asks for permission to hold the aforesaid Congress in Baku, with broad representation from the Turkic peoples of our Union”. The issue was directed by the Presidium of the Union CEC to the Soviet of People's Commissars (Sovnarkom), which in August 1925 gave its consent for convocation of the Turkological Congress in Baku in December of the same year ${ }^{24}$.

The First Turkological Congress in Baku started its proceedings a bit later than it was initially planned - on February 28, 1926, and lasted until March 6. 131 delegates, and not only from the Turkic peoples, were present. It was just the alphabet issue that caused the most animated discussion at the Congress. The cause of latinizarion was favored in several speeches, for instance, in those by N. Yakovlev, L. Zhirkov, U. Aliev, N. Tyuryakulov. Some

19 Smith M. G. Language and Power in the Creation of the USSR. P. 124-125.

20 Zhirkov L. K reforme alfavita vostochnykh narodnostey // Novy Vostok. 1926. No. 11/12. P. 224.

21 In Russian - Всесоюзная научная ассоциация востоковедения.

${ }^{22}$ Pavlovich M. K istorii i zadacham tyurkologicheskogo s"ezda. P. 3.

${ }^{23}$ Agamaly-ogly S. K predstoyashchemu tyurkologicheskomu s"ezdu v Azerbaijane // V bor'be za novy tiurksky alfavit. P. 14.

${ }^{24}$ Pavlovich M. K istorii i zadacham tiurkologicheskogo s"ezda. P. 3-4. 
speakers, first of all, G. Sharaf and G. Ibragimov, continued to defend the Arabic alphabet. They spoke about traditions of the Arabic script rooted in the literature of the Turkic and other Muslim peoples, denied alleged superiority of the Latin alphabet and warned against numerous difficulties and complications, which attempts to implement the script reform suggested by the Latinists would entailed. G. Sharaf, for instance, argued that "substitution of the Arabic script with the Latin, according to all my calculations... will not only fail to promote cultural and economic growth, but will hinder our cultural and economic progress for years" 25 .

Finally, the supporters of the Latinization project took the upper hand. The following resolution, offered by J.Korkmasov, was adopted (by 101 votes, while seven delegates were for the alternative proposal presented by G. Sharaf to put off the final solution to the script issue until the next congress, and nine persons abstained from voting): "Having recognized advantages and technical superiority of the new Turkic-Latin alphabet over the Arabic and the reformed Arabic ones as well as huge cultural-historical and progressive significance of the new alphabet as compared with the Arabic script, the Congress considers introduction of the new alphabet and the way of its implementation in Turkic-Tatar republics and provinces to be at the discretion of each republic and each people". It was followed by a recommendation for "all Turkic-Tatar peoples to study the experience and the implementation method of Azerbaijan and other provinces and republics in the case of possible implementation for themselves" 26 .

The decision was made to establish a unified leading center for coping with issues of introduction of the new alphabet at the all-Union scale. During one of the sessions of CEC of the USSR, while representatives of almost all Turkic republics were present in Moscow, S. Agamaly-ogly on 13 February 1927 invited them to hold a conference, which approved of the suggestion to establish the all-Union Central Committee of the New Turkic Alphabet (VtsK NTA $)^{27}$. S. Agamaly-ogly was elected its chairman. The committee consisted of 39 people, with representation of between one and four persons from each of three Soviet Turkic republics (Azerbaijan, Uzbekistan and Turkmenistan), the Turkic population of Georgia and Armenia, eight autonomous republics, the Karakalpak autonomous province, the North-Caucasian region, as well as ten representatives of the Soviet institutions. Between 3 and 6 June of the same year, the first plenary session of TsK NTA was held in Baku. This plenary assembly paid special attention to the issue of unification of the alphabets. A project of the unified Turkic alphabet was approved of. It was decided to avoid digraphs (transcription of a sound through a combination of two characters) and diacritic signs placed apart from a letter ${ }^{28}$.

The authorities this time were resolute to give a firmer support to the latinization movement. On February 281927 the Organization Bureau (Orgburo) of the Central Committee of the VCP (b) recognized authority of VTsK NTA and decided to grant it funding. CEC officially formulated this decision on May 11 and shortly thereafter the Committee received 500,000 rubles. Formally VTsK NTA was not a governmental body;

${ }^{25}$ Pervyi Vsesoyuznyi Tiurkologicheskyi S'ezd 28 fevralia -6 marta. Stenograficheskyi otchet. Baku, 1926. P. 200-201, 222-223, 233-235, 242-260, 271-278.

26 Ibid. P. 220-221, 321.

27 In Russian - Всесоюзный Центральный комитет нового тюркского алфавита.

28 Nazirov I. Provedenie novogo tiurkskogo alfavita v SSSR i blizhaishie perspektivy // Kul'tura i pis'mennost' Vostoka. 1928. No. 1. P. 13-15; Isaev M. I. Iazykovoe stroitel'stvo v SSSR. P.71. 
it was placed "under supervision" of CEC. As a well-known American researcher of the Soviet ethnic policy Terry Martin has pointed out, this would allow the government to deflect potential Muslim hostility away from the government and direct it onto an "independent" institution, similarly to the attempts in the case of the Union of Militant Godless (Soyuz voinstvuyushchikh bezbozhnikov) in religious affairs. VTsK NTA would use implied governmental support to enforce the issue of latinization, while the government would use stated governmental neutrality to hold VTsK NTA responsible for any problem that might arise $\mathrm{e}^{29}$.

Holding the Turkological Congress and establishing TsK NTA resulted in acceleration of implementing the project of the alphabet reforms. In the Bashkir autonomous republic and in the Turkic union and autonomous republics of Central Asia - Uzbekistan, Kara-Kalpakia, Turkmenistan, Kazakhstan and Kirghizstan - during the second half of the nineteen twenties committees of the new alphabet were established; the alphabets based on the Latin script were developed and approved of by the republican leadership. School education and printing activities began to be gradually transferred to the new alphabets. In some cases, difficulties caused by neo-Arabists' resistance arose. For instance, in Kazakhstan A. Baitursunov was still influential among the people (S. Agamaly-ogly noticed this fact during his trip around the Central Asian republics in 1927). In Uzbekistan, opposition of the Muslim clergy to the implementation of the script reform had to be overcome. For example, mullahs tried to interpret the earthquake in Namangan as manifestation of "the Allah's wrath" at abandonment of the Arabic script. In some cases, technical complications caused dissatisfaction, as it was in Kirghizstan, where the lack of typewriters hindered introduction of the Latin script into the office work. Nevertheless, the alphabet reform in the Turkic Central Asian republics went on and by the end of the decade it had been completed in general ${ }^{30}$.

The Latinization campaign encountered especially stiff resistance in the Volga-Urals region. S. Agamaly-ogly labeled Kazan "the citadel of Islamism". The Academic Center by the Narkompros of the Tatar Republic, where influence of G. Ibragimov and other neo-Arabists was still strong, responded in a negative manner to the decisions of the Turkological Congress in Baku. The treasurer of the Tatar ASSR budget rejected all requests for funding from the Latinists. The Latinists perceived it as nothing less than sabotage. The neo-Arabists responded with retaliatory attack against the Latinists at the 1927 Congress of Tatar Soviets. G. Ibragimov in close cooperation with G. Sharaf and A.Baitursunov created a reformed, unified Arabic script for all of the Turkic speaking peoples of the Volga-Urals and Central Asia ${ }^{31}$. Attempts made by "Yanalif" ("New Alphabet") society to put forward the issue of Latinization of the Tatar press ran into considerable resistance. The neo-Arabists convoked their own Turkological congress in Kazan, which they, taking advantage of the presence of representatives of some other republics and provinces, tried to pass for an all-Union assembly. Eventually, the party leadership made the decision to uphold the latinization: the committee of the Republican Party obliged the party functionaries to as-

${ }^{29}$ Martin T. The Affirmative Action Empire. Nations and Nationalism in the Soviet Union, 19231939. Ithaca and London, 2001. P. 189.

30 Agazade F., Karakashly K. Ocherk po istorii razvitia dvizhenia novogo alfavita... P.90-121; Kul'besherov B. Itogi 2-go Plenuma Vsesoyuznogo tsentral'nogo komiteta novogo tiurkskogo alfavita. P. 1011; Isaev M. I. Iazykovoe stroitel'stvo v SSSR. P. 83-108.

31 Smith M. G. Language and Power in the Creation of the USSR. P. 128. 
sist the reform and allowed introduction of the new alphabet in secondary and technical schools. In the late nineteen twenties, movement for the new alphabet led by "Yanalif" society became more active, although the resistance of the neo-Arabists had not been overcome completely ${ }^{32}$.

Some difficulties arose in the Crimea with introducing the new alphabet to the local Tatars and Karaites. An idea of Latinization of the Crimean Tatar language first appeared already in 1905. An issue of transition to the new alphabet was raised at the conference convoked by the Academic Council of the Crimean Narkompros in October 1924. The former leadership of the Crimean CEC with V. Ibragimov as its head opposed the alphabetic reform. Along with the neo-Arabists, supporters of the ancient Jewish alphabet among the Karaites (who, in spite of their Turkic origin, practiced Judaism) also spoke out against latinization. Real work on introduction of the new alphabet was started once the first groups of the society of friends of NTA were organised in Simferopol. They were formed on the initiative of some members of the Crimean delegation, which had taken part at the all-Union Turkological Congress. The Crimean committee of the new alphabet was established by a decree of the Presidium of the Crimean CEC in July 1927. In 1929, a scholarly conference was held in Simferopol, which made a decision on transition to the latinized alphabet, later confirmed by the governmental institutions ${ }^{33}$.

During the same period, the alphabetic Latinization started to involve the literary non-Turkic languages spoken by ethnic groups which also traditionally practiced Islam. For instance, the committee of the new alphabet functioned in Tajikistan from 1927 on, and in November 1928 the project of the new Latinized Tajik alphabet was approved of ${ }^{34}$. The alphabetic reforms started already in the early nineteen twenties continued in the Northern Caucasus. The cause did not proceed too fast in view of the resistance from the conservative strata of the population, first of all the Muslim clergy. Anyway, the process continued, and accelerated after the establishment of the regional branch of the Tsentrizdat (Central Publishers), which in 1925 was merged with the regional committee of the new alphabet. Following the example of Northern Ossetia, Ingushetia, Kabarda and Karachai-Balkaria, where the new alphabet had been introduced in general by the end of 1924, Latinization started to be implemented in Chechnya and Circassia since 1925, and since 1927 - in Adygea ${ }^{35}$. A. Khajiev, chairman of the regional committee of NA, stated in his speech at the plenary assembly of VTsK NTA in Alma-Ata in May 1930: "The Latin script is the script of industry, of machinery and socialism. Having evolved as a counterweight to the Arabic script, based on hand technique of the Middle Ages, it has taken root among the toiling people of the Northern Caucasus, in spite of furious resistance from the fanatical clergy and Russified intellectuals for this script has enabled, as one of the main elements, development of the productive forces of the national regions of the Northern Caucasus"36.

32 Khansuvarov I. Latinizatsia - orudie leninskoi natsional'noi politiki. Moscow, 1932. P. 13-14.

${ }^{33}$ Ibid. P. 15-16; Isaev M. I. Iazykovoe stroitel'stvo v SSSR. P. 118.

34 Shukurov M. R. Istoria kul'turnoi zhizni v Sovetskom Tajikistane (1917-1941). Dushanbe, 1970. P. 98-104.

35 Aliev U. Kul'turnaya revoliutsia i latinizatsia // Kul'tura i pis'mennost' Vostoka. 1928. No.2. P.25; Takhtamyshev K. Latinizatsia na Severnom Kavkaze // Revoliutsia i pis'mennost'. 1932. No. 4/5. P. 80.

36 Khajiev A. Latinizatsia i unifikatsia gorskikh alfavitov na Severnom Kavkaze // Kul'tura i pis'mennost' gorskikh narodov Severnogo Kavkaza. Vladikavkaz, 1930. P.7. 
In Dagestan, alphabetic reforms started later, and attempts of their implementation encountered the greatest difficulties. On the one hand, it was connected with special ethno-linguistic situation in the region, with plenty of languages and dialects. On the other hand, positions of conservative nobility and clergy were especially strong there. In the early twentieth century, there were 1700 mosques and more than 740 Muslim schools ${ }^{37}$. According to I. Aliev, the people's commissar of education of the republic, "prerevolutionary Dagestan was a cradle of Arabism and served as a provider of the clergy for the whole Muslim part of the Caucasus and often beyond it" 38 . Decisions of the Baku Congress of 1926 also influenced the cause of the alphabetic reform in Dagestan. In October 1927 the republican Sovnarkom approved of the plan of introduction of the new alphabet. In August 1928 CEC and Sovnarkom of Dagestan confirmed the project of transition of school instruction and office work from the Arabic script to the Latin one. Finally, on November 141929 the Third Session of CEC of Dagestan passed the decree "On obligatory and complete transition to the new latinized alphabet". According to it, the new alphabet of Dagestan was to become the only state alphabet for the main languages of the republic starting from October $11930^{39}$.

At the turn of the decade, VTsK NA was coping with issues of introducing latinized alphabets to more languages, including those of non-Turkic and non-Muslim peoples. The point was about Latinization of not only Arabic and Cyrillic scripts, but also of other kinds of writing, including Chinese and Korean hieroglyphic scripts. Projects of new alphabets for the languages of smaller indigenous peoples of the Russian North and Siberia, who had not previously had their own writing, were also based upon the Latin script. Between 1930 and 1932, alphabets for several languages of Siberia and Altai, the Fennic languages of Tver Karelians, Vepses and Ingrians, 14 peoples of the North were developed and adopted. The "unified alphabet of the Mongol ethnic group" on the base of the Latin script was confirmed at the "Conference of the Mongol ethnic group on script and language issues” held in Moscow in January 1931. In September 1931 the Latinized Chinese alphabet was adopted at the all-Union conference on Latinization of the Chinese script in Vladivostok ${ }^{40}$. By 1932, altogether 66 national alphabets had been latinized, and development of seven more was in progress by the end of the same year ${ }^{41}$.

Policy of the alphabet Latinization reached its peak in the early nineteen thirties. Later on, however, it began to slow down. Among the Volga Eastern-Fennic peoples and the Turkic-speaking Chuvashs, the process of Latinization discontinued. Only in Komi ASSR the Latin script was really introduced. In Udmurtia, the Latinization project met with serious resistance. Its opponents charged the supporters of Latinization with orientation towards "bourgeois" Finland. One of the local activists regarded the Latin script as "a reactionary alphabet, used as a mighty weapon in the hands of the Catholic clergy" 42 . Already

${ }^{37}$ Magidov Sh.G. Problema iazyka obuchenia i pis'mennosti narodov Dagestana v kul'turnoi revoliutsii. Makhachkala, 1971. P. 85.

38 Aliev I. Piat' let bor'by za novyi alfavit v Dagestane // Revoliutsia i pis'mennost'. 1932. No. 3. P. 51.

39 Magidov Sh.G. Problema iazyka obuchenia i pis'mennosti narodov Dagestana. P. 86-91.

40 Khansuvarov I. Latinizatsia - orudie leninskoy natsional'noy politiki. P. 26; Laikhter M. O latinizatsii kitaiskoy pis'mennosti // Kul'tura i pis'mennost' Vostoka. 1931. No. 9. P.25-28.

41 Martin T. The Affirmative Action Empire. P. 203.

42 Ivanov T. Ob unifikatsii udmurtskogo (votskogo) alfavita // Kul'tura i pis'mennost' Vostoka. 1931. No.7/8. P. 168-169; Grande B. Latinizatsia pis'ma v Udmurtskoy A. O. // Revoliutsia i pis'mennost'. 1933. No. 1. P. 59-60. 
in 1928, the all-Union congress of the Jewish cultural workers rejected an idea of latinizing the Jewish script ${ }^{43}$. Critical notes on various aspects of Latinization policy in the press were becoming more and more frequent. The idea of latinizing the very Russian alphabet, promoted by N. F. Yakovlev and backed up by A. V. Lunacharsky, faced a powerful and varied opposition. Respectable linguists D. N. Ushakov, M. N. Peterson and G. O. Vinokur as well as a well-known specialist in the field of the Slavic languages N.S. Derzhavin (rector of the Petrograd/Leningrad University between 1922 and 1925) were unequivocally opposed to it ${ }^{44}$. Eventually, this idea failed.

New trends in approach towards the alphabet question and towards language issues in general from the mid-thirties were connected with revision of the common grounds of the Soviet ethnic policy. The period was marked by rehabilitation of the Russian culture and history and of "Russianism" (Russkost') as a whole. The notion of "great-power chauvinism" (with implication of the Russian chauvinism) was disappearing from academic and public discourses. Labelling tsarist Russia a "prison of peoples", typical of the previous period, was no longer in use. In the historical science, views of M.N. Pokrovsky and his "school"came under severe criticism. Instead, study and instruction of the national history in partriotic terms was introduced in schools with an emphasis on, on positive consequences of annexing various regions to Russia. More attention was paid to the importance of the Russian language as the means of interethnic communication within the federal state. The party and state leaders tended to understand that functioning of literary languages of the ethnic minorities on the base of the Latin script complicated the study of the Russian language. At the same time, an idea of the "world revolution" disappeared completely from the public discourse. Thence the need for studying European languages, which should be assisted by knowledge of the Latin alphabet, was no longer vital.

Since the mid-thirties messages from various regions had been coming about the unsuitability of the Latin script to phonetics and typographic needs of some languages. On 1 July 1935 the Presidium of the CEC of the USSR in discussing activities of the KNA evaluated the transition of the alphabets, which had earlier used the Cyrillic script, to the Latin base (Udmurt, Komi, Ossetian, Yakut, etc.) as a serious mistake ${ }^{45}$. In February 1937 the Seventh Plenum of the VTsK NA confirmed transition of the alphabet of the Abkhazian-Adygean languages of the Northern Caucasus and some languages of the North and Siberia (Saami, Nenets, Khanty, Mansi, Nanais, Nivkhs) from the Latin script to the Cyrillic base ${ }^{46}$.

During 1937 and 1938, decrees on adoption of the Cyrillic script were issued in the autonomous republics and provinces of the Northern Caucasus. The first of them, on July 201937 was passed in Dagestan by the presidium of the republican CEC ("On transition of the writing system of the Dagestan peoples to the Russian script") ${ }^{47}$. Soon thereafter governing bodies of other North Caucasian autonomies followed suit. In a comment to one of these decrees, signed by the deputy manager of the school department of the party Central Committee, it was noted that "implementation of this decree, first, will ease spell-

${ }^{43}$ Zaretsky A. K probleme latinizatsii evreiskogo pis'ma // Revoliutsia i pis'mennost'. 1932. No. 1/2. P. 20.

44 Smith M. G. Language and Power in the Creation of the USSR. P. 104-105.

${ }^{45}$ Isaev M. I. Iazykovoe stroitel'stvo v SSSR. P. 254-255.

46 Smith M. G. Language and Power in the Creation of the USSR. P. 157.

47 Magidov Sh. G. Problema iazyka obuchenia i pis'mennosti narodov Dagestana. P. 118-119. 
ing of international terms and names (they will coincide with their orthography in the Russian language); second, adoption of the Russian alphabet will promote more successful study of the Russian language and increase literacy of the pupils, and third, in view of the already completed transition of the peoples of Dagestan to the Russian alphabet leaving the writing system of the peoples of the Circassian and Karachai autonomous provinces on the Latin base would be impractical" 48 . In Azerbaijan and the Turkic union, and autonomous republics of Central Asia and the Volga-Urals region similar decrees were passed in 1939 and $1940^{49}$. On 21 May 1940, the law on transition of the Tajik alphabet from the Latin script to the Russian one was passed by the Supreme Soviet of the Tajik SSR ${ }^{50}$.

The Russian language was taught everywhere at schools as the second language. Corresponding decision was made in October 1937 at a Plenum of the CC of the Communist party. On 13 March 1938, a decree by the Sovnarkom and the CC VCP (b) "On obligatory instruction of the Russian language at schools of the national republics and provinces" was passed ${ }^{51}$. On July 1939 of the same year "Pravda" newspaper reported that the Russian language was becoming an international language of the socialist culture, "like the Latin language had been for the ruling strata in the early Middle Ages, and the French language - in the eighteenth and nineteenth centuries". In 1939, it was declared that as the cultural level of the peoples of the USSR grew, the latinized alphabet ceased to satisfy the needs of development of the languages since it failed to guarantee all conditions for rapprochement with the culture of the great Russian people ${ }^{52}$.

Some indigenous minorities of the Russian North-West, North and Siberia, whose written languages had been created in the thirties, found themselves again without writing. It happened, for example, to the Vepses and Ingrians. In total, eleven small peoples had lost their written languages ${ }^{53}$. Moreover, by the late thirties the use of the Latin alphabet in the territory of the Soviet Union had stopped almost completely. School education, any cultural work and publishing activities in the languages of several European diasporas such as Finnish, Estonian, Latvian, Polish, German, etc., discontinued. Only Karelia, which in spring of 1940 was transformed into a union republic under the name "Karelian-Finnish", was an exception to the rule. There a short-lived experiment with a largely artificial Karelian literary language developed in the late thirties, which was based upon the Cyrillic script and had numerous lexical borrowings from Russian, ceased and the official position of the Finnish language, cancelled in 1938 was restored in the republic ${ }^{54}$.

Political and social developments of the second half of the thirties in the USSR were often accompanied by repressions, and script reforms were not exceptional to the rule. M. Pavlovich and S. Agamaly-ogly had died long before the "great terror" of the late thirties, in 1927 and 1930 accordingly. N. F. Yakovlev and L. I. Zhirkov were among the few

48 Spravka k postanovleniu Politburo TsK VKP (b) 23.02.1938 (Comment on the resolution of the Political Bureau of the CC of the UCP (b) dd. 23 February 1938) // RGA SPI (Russian State Archive of the Social-Political Documents). F. 17. Op. 114. D. 846. L.5.

${ }^{49}$ Voprosy sovershenstvovania alfavitov tiurkskikh narodov SSSR. Sbornik statei. Moscow, 1972. P. 35-103.

50 Shukurov M. R. Istoria kul'turnoy zhizni v Sovetskom Tajikistane. P. 249-250.

51 Vdovin A. I. "Rossiyskaia natsia". Natsional'no-politicheskie protsessy XX veka i obshchenatsional'naia rossiiskaia idea. Moscow, 1995. P. 99.

52 Ibid. P. 102.

53 Baziev A. T., Isaev M. I. Iazyk i natsia. Moscow, 1973. P. 121.

${ }^{54}$ Hyytiä O. Karjalais-Suomalainen Neuvostotasavalta. Kansallinen tasavalta? Helsinki, 1999. S. $12,15$. 
who avoided arrest and further on lived and worked in peace. Other prominent Latinists, including J. Korkmasov, U. Aliev, B. Choban-zade and E. D. Polivanov fell victims of standard accusations of bourgeois nationalism, espionage, etc. and were either sentenced to death or died in jails and prison camps. The same sad fate awaited their former opponents neo-Arabists, among whom were A. Baitusunov and G. Ibragimov. G. Sharaf was also arrested but managed to survive and was released after eight years of imprisonment. However, his health was undermined, and he died in $1950^{55}$.

Curtailing the process of Latinization and the opposite trend of substituting the Latin script with the Cyrillic one started in the mid-thirties was concerned with the revision of the general points of the Soviet ethnic policy, first of all with abandonment of the main principles of indigenization. One can see here also a reflection of a partial rehabilitation of the historic role of the Russian culture and promotion of the Russian nation to the position of "the first among the equal ones" among the peoples of the USSR.

\section{References}

Agazade F., Karakashly K. An Essay on the History of Development of the Movement for the New Alphabet and Its Acheivements. Kazan, VtsK NTA Publ., 1928, 133 p. (In Russian)

Grande B. Script Latinization in the Udmurt AO. Revoliutsia i pis'mennost', 1933, no. 1, pp. 57-63. (In Russian)

Hyytiä O. Karjalais-Suomalainen Neuvostotasavalta. Kansallinen tasavalta? Helsinki, Suomalaisen Kirjallisuuden Seura, 1999, $210 \mathrm{p}$.

Isaev M. I. Language Construction in the USSR (Processes of Creation of the Writing of the Soviet Peoples. Moscow, Nauka Publ., 1979, 372 p. (In Russian)

Ivanov T. On Unification of the Udmurt (Vote) Alphabet. Kul'tura i pis'mennost' Vostoka. 1931, no. 7/8, pp. 165-172. (In Russian)

Khajiev A. Latinization and Unification of the Highland Alphabets in the Northern Caucasus. Kul'tura $i$ pis'mennost' gorskikh narodov Severnogo Kavkaza. Vladikavkaz, Publ. of the Regional Committee of NA, 1930, pp. 5-20. (In Russian)

Khansuvarov I. Latinization as an Instrument of the Leninist Ethnic Policy. Moscow, Party Publ., 1932, 39 p. (In Russian)

Kul'besherov B. Results of the Second Plenum of the All-Union Central Committee of the New Turkic Alphabet and Current Tasks of the Cause of Introducing this Alphabet. Kul'tura i pis'mennost' Vostoka. 1928, no. 2, pp. 6-21. (In Russian)

Laikhter M. On Latinization of the Chinese Script. Kul'tura i pis'mennost' Vostoka. 1931, no.9, pp.22-32. (In Russian)

Magidov Sh. G. The Issue of the Language of Instruction and of the Script of the Dagestan Peoples in the Cultural Revolution. Makhachkala, Daguchpedgiz Publ., 1971, 128 p. (in Russian)

Martin T. The Affirmative Action Empire. Nations and Nationalism in the Soviet Union, 1923-1939. Ithaca and London, Cornell University Press, 2001, 496 p.

Nazirov I. Introduction of the New Turkic Alphabet in the USSR and the nearest Prospects. Kul'tura $i$ pis'mennost' Vostoka. 1928, no. 1, pp.11-33. (In Russian)

Shukurov M. R. History of the Cultural Life in Soviet Tajikistan. Dushanbe, Irfon Publ., 1970, 494 p. (In Russian)

Smith M.G. Language and Power in the Creation of the USSR 1917-1953. Berlin; New York, Mouton de Gruyter, 1998, $294 \mathrm{p}$.

Vdovin A. I. The Russian Nation. National-Political Processes of the $20^{\text {th }}$ Century and the Nationwide Russian Idea. Moscow, Libris Publ., 1995, 247 p. (In Russian)

Yuzbashev N. The Arab and the New Turkic Alphabet. Kul'tura i pis'mennost' Vostoka. 1928, no. 1, pp.66-69. (In Russian)

${ }^{55}$ Litvin A. L. Smert' uchenogo // Zapret na zhizn'. Kazan, 1993. P. 173-179; Ursu D. P. Bekir Chobanzade. Zhizn', sud'ba, epokha. Simferopol, 2004. P. 254; Abdullaev M. A. Veliky dagestanets - Jelal-Ed-Din Korkmasov. Zhizn', deiatel'nost' i sotsial'no-politicheskie vozzrenia. Makhachkala, 2017. P. 168. 
Zak L.M., Isaev M.I. Problems of the Writing of the Soviet Peoples in the Cultural Revolution. Voprosy istorii. 1966, no. 2, pp.3-20. (In Russian)

Zaretsky A. On the Issue of Latinization of the Jewish Script. Revoliutsia i pis'mennost'. 1932, no. 1/2, pp. 1532. (In Russian)

Zhirkov L. Reforming the Alphabet of the Eastern Peoples. Novyi Vostok. 1926, no.11/12, pp.223-235. (In Russian)

Received: February 23, 2019

Accepted: September 9, 2019

Статья поступила в редакцию 23 февраля 2019 г.

Рекомендована в печать 9 сентября 2019 г. 